Article

\title{
Potential Development of Tumor-Targeted Oral Anti-Cancer Prodrugs: Amino Acid and Dipeptide Monoester Prodrugs of Gemcitabine
}

\author{
Yasuhiro Tsume, Adam J. Drelich, David E. Smith and Gordon L. Amidon * \\ Department of Pharmaceutical Science, College of Pharmacy, University of Michigan, 428 Church Street, \\ Ann Arbor, MI 48109-1065, USA; ytsume@umich.edu (Y.T.); ajdrelic@umich.edu (A.J.D.); \\ smithb@med.umich.edu (D.E.S.) \\ * Correspondence: glamidon@umich.edu; Tel.: +1-734-764-2464; Fax: +1-734-763-6282
}

Received: 26 July 2017; Accepted: 5 August 2017; Published: 10 August 2017

\begin{abstract}
One of the main obstacles for cancer therapies is to deliver medicines effectively to target sites. Since stroma cells are developed around tumors, chemotherapeutic agents have to go through stroma cells in order to reach tumors. As a method to improve drug delivery to the tumor site, a prodrug approach for gemcitabine was adopted. Amino acid and dipeptide monoester prodrugs of gemcitabine were synthesized and their chemical stability in buffers, resistance to thymidine phosphorylase and cytidine deaminase, antiproliferative activity, and uptake/permeability in HFF cells as a surrogate to stroma cells were determined and compared to their parent drug, gemcitabine. The activation of all gemcitabine prodrugs was faster in pancreatic cell homogenates than their hydrolysis in buffer, suggesting enzymatic action. All prodrugs exhibited great stability in HFF cell homogenate, enhanced resistance to glycosidic bond metabolism by thymidine phosphorylase, and deamination by cytidine deaminase compared to their parent drug. All gemcitabine prodrugs exhibited higher uptake in HFF cells and better permeability across HFF monolayers than gemcitabine, suggesting a better delivery to tumor sites. Cell antiproliferative assays in Panc- 1 and Capan-2 pancreatic ductal cell lines indicated that the gemcitabine prodrugs were more potent than their parent drug gemcitabine. The transport and enzymatic profiles of gemcitabine prodrugs suggest their potential for delayed enzymatic bioconversion and enhanced resistance to metabolic enzymes, as well as for enhanced drug delivery to tumor sites, and cytotoxic activity in cancer cells. These attributes would facilitate the prolonged systemic circulation and improved therapeutic efficacy of gemcitabine prodrugs.
\end{abstract}

Keywords: gemcitabine prodrugs; stroma cells; pancreatic cancer; metabolism; cytosine deaminase

\section{Introduction}

Gemcitabine, 2' $2^{\prime}$-difluoro-2'-deoxycytidine, $\mathrm{dFdC}\left(\mathrm{Gemzar}^{\mathrm{TM}}\right)$ is a cancer drug that is clinically used as a first line treatment for pancreatic cancer and other cancers [1,2]. Gemcitabine is incorporated into DNA synthesis to inhibit cell growth. Like most anticancer drugs, gemcitabine, which is an antimetabolite like floxuridine, is administered intravenously and has a broad spectrum to treat various cancers [3]. However, the adverse effects associated with those chemotherapeutic agents remain severe and many efforts have been made to minimize adverse effects and maximize therapeutic efficacy. Prodrug strategies have been employed to overcome unfavorable physicochemical properties of the drug for the improvement of oral bioavailability and/or the minimization of toxic side effects. Amino acid and dipeptide monoester prodrugs of poorly permeable anticancer and antiviral drugs have been developed and investigated for their improved oral bioavailability and metabolic disposition [4-21]. 
Amino acid ester prodrugs and nucleoside analogs have been shown to be substrates for uptake transporters for PEPT1, PEPT2, $\mathrm{ATB}^{0,+}, \mathrm{ENT} 1$, and CNT in the small intestine and other tissues, respectively, and their improved oral bioavailability is attributed by those carrier-mediated mechanisms [22-36]. Even though PEPT1 is stereoselective and exhibits greater affinity for L-enantiomers of amino acids than D-enantiomers, PEPT1 still improves the membrane permeability and overall oral absorption of prodrugs with D-amino acids [37,38]. Amino acid monoester prodrugs like valacyclovir significantly enhanced the oral bioavailability of their parent, acyclovir, and several reports suggest that absorption improvement was attributed by oligopeptide transporters $[35,36,39,40]$. Nucleoside analogs like gemcitabine and floxuridine are mainly transported through nucleoside transporters into the cell, and those transporters are highly expressed in tumor tissues [1,28]. Amino acid ester prodrugs of nucleotide analogs may facilitate enhanced delivery to pancreatic ductal cancer cells such as Panc-1 and Capan-2, since these cells express potential target transporters at high levels $[28,41]$.

Gemcitabine is systematically converted to triphosphated gemcitabine by enzymes after being transported into cells and inhibits DNA synthesis [3]. However, gemcitabine is rapidly converted to $\mathrm{dFdU}$ in many tissues, including the liver, by the enzyme cytidine deaminase (CDA), while floxuridine, which has similar structure to gemcitabine, is rapidly converted to 5-fluorouracil (5-FU) by the enzyme thymidine phosphorylase (TP) [28,42-44]. As a consequence, higher doses of nucleoside analogs are required to display clinical efficacy, which leads to greater toxicity. Therefore, protection of the deamination and glycosidic bond of gemcitabine and floxuridine is required to maintain the high potency of these drugs and to direct the robust inhibition of DNA synthesis. Improving the chemical and enzymatic stability of nucleoside analogs to CDA and TP by prodrug approaches could enhance its therapeutic efficacy and obviate toxicity concerns.

Although amino acid monoester prodrugs of gemcitabine have exhibited enhanced PEPT1-mediated transport, as well as enzymatic activation in pancreatic cancer surrogate cell systems, gemcitabine prodrugs have to improve their stability because they still need to cross a number of tissue barriers including stromal cells to targeted tumors $[16,38,45,46]$. D-Amino acid monoester prodrugs of gemcitabine may be delivered to a greater extent at the target site by carrier-mediated transporters and permeated through tumor stroma more than L-amino acid monoester prodrugs due to the elongated systemic circulation time $[47,48]$. In this report, we describe the stability, membrane permeability, and proliferative activity of gemcitabine prodrugs with stereospecific, L-/D-amino acids, and the dipeptide L-phenylalanyl-L-tyrosine in surrogate cell systems, including the stromal environment. Uptake and permeability of gemcitabine prodrugs were evaluated with HFF cells, a surrogate for stroma cells, to determine the feasibility to deliver drugs to tumors and the advantage/disadvantage of gemcitabine prodrugs over the parent drug gemcitabine. The chemical/enzymatic stability and the enzymatic activation of the prodrugs in Panc- 1 and Capan-2 cell homogenates were also evaluated to determine the effects of the amino acid/dipeptide promoiety structure on enzyme-mediated activation. The feasibility of antiproliferative action of selective amino acid/dipeptide gemcitabine prodrugs was also explored using cancer cells that overexpress PEPT1 as well as non-tumoral epithelial cells (MDCK cells) to evaluate the possibility of improved therapeutic efficacy at tumor sites.

\section{Results}

\subsection{Chemical and Enzymatic Stability Studies}

The experiments concerning prodrug stability were performed at $37^{\circ} \mathrm{C}$ in $\mathrm{pH} 7.4$ phosphate buffer, in HFF and MDCK cell homogenates, and in pancreatic cancer cell homogenates, Panc-1 and Capan- 2 cells. The estimated half-lives $\left(t_{1 / 2}\right)$ obtained from linear regression of pseudo-first-order plots of prodrug concentration vs. time for Gem prodrugs in $\mathrm{pH} 7.4$ phosphate buffers alone, and in MDCK, Panc-1, and Capan-2 cell homogenates, are listed in Table 1 along with previously reported results for the comparison purpose. No significant degradation of Gem and gemcitabine prodrugs was observed 
in HFF cell homogenate over $120 \mathrm{~min}$ (data not shown). Prodrug metabolites such as Gem and cytosine were monitored along with prodrug disappearance in this experiment. However, mass balance was not achieved because cytosine was metabolized even further (Figure 1). $5^{\prime}$-D-valyl-gemcitabine exhibited the highest stability in all media tested and $5^{\prime}$-L/D-valyl-gemcitabine did not metabolize in MDCK cells. The dipeptide prodrug, $5^{\prime}$-L-phenylalanyl-tyrosyl-gemcitabine, was chemically less stable compared to amino acid prodrugs, due to the possible formation of diketopiperazine by a dipeptide promoiety, and exhibited 4-fold faster metabolism/activation in cell homogenates compared to one in buffer ( $\mathrm{pH} 7.4$ ). All prodrugs exhibited 4- to 87-fold shorter half-lives in cell homogenates than in $\mathrm{pH} 7.4$ phosphate buffer, suggesting enzyme-catalyzed hydrolysis. The composition of the amino acids in $5^{\prime}$ position exerted a profound effect on the stability of the ester bond, especially gemcitabine prodrugs, with an unnatural form (D-) of amino acid enzymatically more stable than one with natural form (L-) of amino acid (Table 1).<smiles>[R]CC1OC2OC1C(O)C2F</smiles><smiles></smiles>

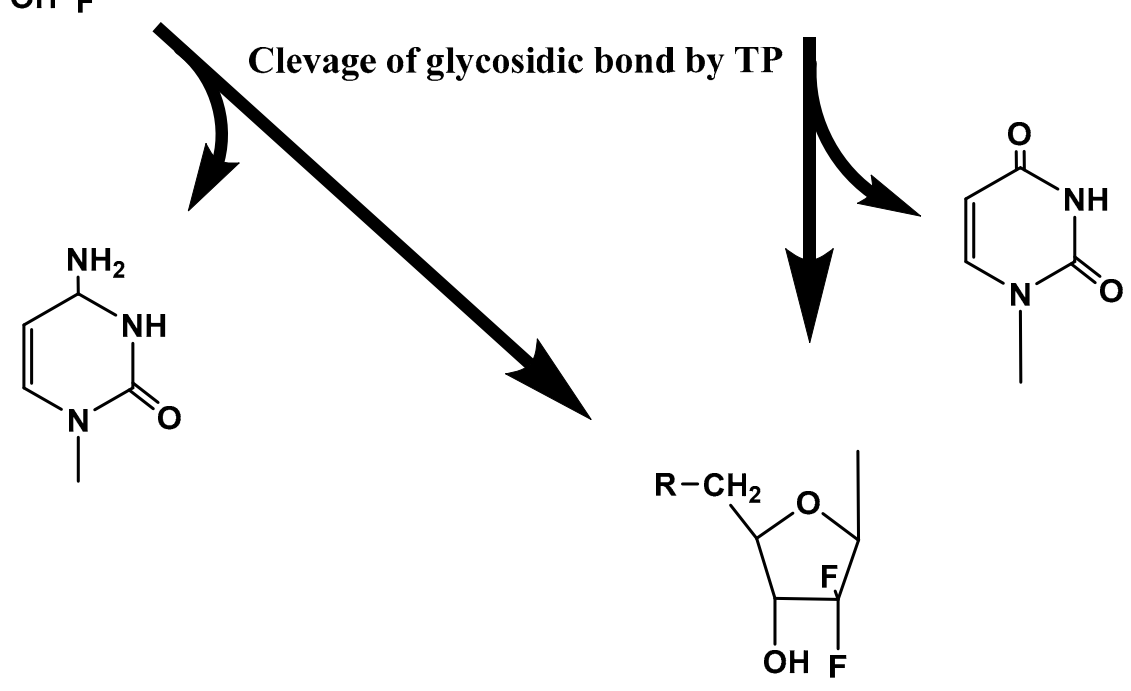

$\mathrm{R}=$ amino acid/dipeptide side chain
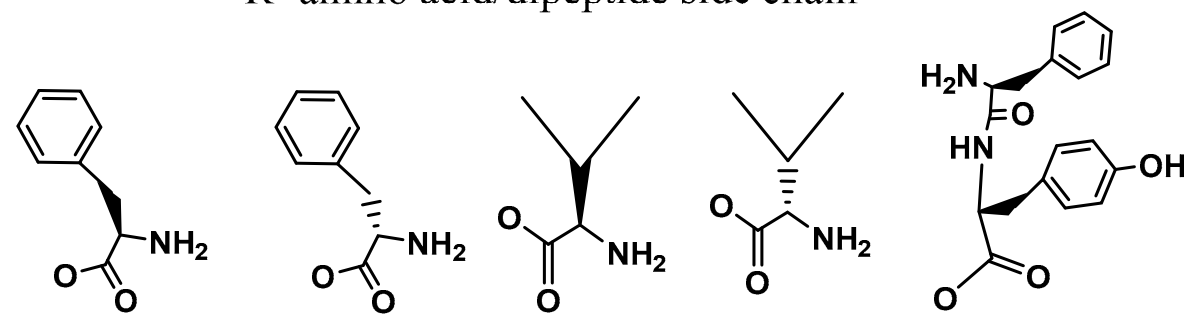

L-Phenylalanine D-Phenylalanine L-Valine

D-Valine L-Phenylalanyl-L-Tyrosine

Figure 1. The metabolic pathway of gemcitabine and gemcitabine prodrugs with relevant enzymes. 
Table 1. Stability of gemcitabine prodrugs in pH 7.4 Buffer and pancreatic cancer cell homogenates. (Mean \pm S.D., $n=3$ ).

\begin{tabular}{|c|c|c|c|c|}
\hline Prodrug & $\begin{array}{c}\text { Buffer pH } 7.4 \\
\mathbf{t}_{1 / 2}(\mathrm{~min})\end{array}$ & $\begin{array}{c}\text { Panc-1 Cell } \\
\text { Homogenates } \\
t_{1 / 2}(\min )\end{array}$ & $\begin{array}{c}\text { Capan-2 Cell } \\
\text { Homogenates } \\
t_{1 / 2}(\min )\end{array}$ & $\begin{array}{c}\text { MDCK Cell } \\
\text { Homogenates } \\
\mathbf{t}_{1 / 2}(\min )\end{array}$ \\
\hline Gemcitabine & $>120 *$ & $>120 \#$ & $5.2 \pm 2.4$ & $72.9 \pm 29.1$ \\
\hline $\begin{array}{l}\text { Mono amino acid prodrugs } \\
\text { 5'-L-Phenylalanyl-gemcitabine } \\
\text { 5'-D-Phenylalanyl-gemcitabine } \\
\text { 5'-L-Valyl-gemcitabine } \\
\text { 5'-D-Valyl-gemcitabine }\end{array}$ & $\begin{array}{l}>120 * \\
>120 * \\
>120 * \\
>120 *\end{array}$ & $\begin{array}{l}9.8 \pm 1.2 \\
29.2 \pm 5.7 \\
23.9 \pm 0.7 \\
>120\end{array}$ & $\begin{array}{c}1.4 \pm 0.1 \\
14.2 \pm 0.4 \\
4.8 \pm 1.3 \\
>120\end{array}$ & $\begin{aligned} 4.8 & \pm 1.2 \\
94.9 & \pm 15.7 \\
> & 120 \\
> & 120\end{aligned}$ \\
\hline $\begin{array}{l}\text { Dipeptide prodrugs } \\
\text { 5'-L-Phenylalanyl-L-tyrosyl- } \\
\text { gemcitabine }\end{array}$ & $33.6 \pm 1.4$ & $30.2 \pm 1.1 \#$ & $8.0 \pm 2.3$ & $60.2 \pm 2.3$ \\
\hline
\end{tabular}

\subsection{Thymidine Phosphorylase Activity against Gemcitabine and Gemcitabine Prodrugs}

The metabolic stability of Gem and Gem prodrugs was assessed using the pure enzyme, thymidine phosphorylase. The results shown in Table 2 indicate that Gem was rapidly degraded to the less active metabolite, cytosine, by thymidine phosphorylase. The amino acid and dipeptide monoester prodrugs of Gem were found to be quite resistant to degradation by thymidine phosphorylase. Gem prodrugs were, at least, 5- to 10-fold more stable than Gem to degradation by thymidine phosphorylase. The half-lives of $5^{\prime}$-D-phenylalanyl-gemcitabine, $5^{\prime}$-L-valyl-gemcitabine, and $5^{\prime}$-D-valyl-gemcitabine were in excess of $120 \mathrm{~min}$, reflecting their superior resistance to metabolic degradation by thymidine phosphorylase.

Table 2. Stability of gemcitabine and gemcitabine prodrugs in the presence of thymidine phosphorylase (mean \pm S.D., $n=3$ ).

\begin{tabular}{ll}
\hline Prodrug/Drug & $\mathbf{t}_{\mathbf{1 / 2}}(\mathbf{m i n})$ \\
\hline Gemcitabine & $6.0 \pm 1.8^{*}$ \\
\hline Mono amino acid prodrugs & \\
\hline 5'-L-Phenylalanyl-gemcitabine & $31.9 \pm 5.0 *$ \\
5'-D-Phenylalanyl-gemcitabine & $>120 *$ \\
5'-L-Valyl-gemcitabine & $>120 *$ \\
5'-D-Valyl-gemcitabine & $>120 *$ \\
\hline Dipeptide prodrugs & \\
\hline 5'-L-Phenylalanyl-L-tyrosyl-gemcitabine & $63.0 \pm 0.3$ \\
3'-L-Valyl-gemcitabine & $56.0 \pm 6.9$ \\
\hline \multicolumn{2}{c}{${ }^{\prime}$ Previously reported [38]. }
\end{tabular}

\subsection{Cytidine Deaminase Activity against Gemcitabine and Gemcitabine Prodrugs}

The metabolic stability of Gem and Gem prodrugs was assessed using the pure enzyme, CDA. The results shown in Table 3 indicate that Gem was rapidly deaminated to the less active metabolite, $\mathrm{dFdU}$, by CDA. The amino acid and dipeptide monoester prodrugs of Gem were found to be quite resistant to deamination by CDA. Gem prodrugs were, at least, 15-fold more stable than Gem to degradation by CDA. The half-lives of $5^{\prime}$-D-phenylalanyl-gemcitabine, $5^{\prime}$-L-valyl-gemcitabine, $5^{\prime}$-D-valyl-gemcitabine, and 5'-L-phenylalanyl-L-tyrosyl-gemcitabine were in excess of $120 \mathrm{~min}$, reflecting their superior resistance to metabolic degradation by CDA. 
Table 3. Stability of gemcitabine and gemcitabine prodrugs in the presence of cytidine deaminase (mean \pm S.D., $n=3$ ).

\begin{tabular}{lc}
\hline Prodrug/Drug & $\mathbf{t}_{\mathbf{1 / 2}}(\mathbf{m i n})$ \\
\hline Gemcitabine & $<3$ \\
\hline Mono amino acid prodrugs & \\
\hline 5'-L-Phenylalanyl-gemcitabine & $44.6 \pm 18.8$ \\
5'-D-Phenylalanyl-gemcitabine & $>120$ \\
5'-L-Valyl-gemcitabine & $>120$ \\
5'-D-Valyl-gemcitabine & $>120$ \\
\hline Dipeptide prodrugs & $>120$ \\
\hline 5'-L-Phenylalanyl-L-tyrosyl-gemcitabine & \\
\hline
\end{tabular}

\section{4. $\left[{ }^{3} \mathrm{H}\right]$ Gly-Sar Uptake Inhibition}

The $\mathrm{IC}_{50}$ values of Gem and Gem Prodrugs for the intake transporters, PEPT1, determined using inhibition of Gly-Sar uptake in Caco-2 cells, are summarized in Table 4. All Gem prodrugs exhibited greater affinity for the intake transporter than their parent, Gem. Gem exhibited minimal inhibitory activity of Gly-Sar uptake into Caco-2 cells and the $\mathrm{IC}_{50}$ value was $26.8 \pm 9.3 \mathrm{mM}$. All gem prodrugs exhibited an 8- to 38 -fold better $\mathrm{IC}_{50}$ value than $\mathrm{Gem}$. Among them, $5^{\prime}$-L-phenylalanyl-gemcitabine exhibited the highest affinity ( $\left(\mathrm{IC}_{50}\right.$ value $0.7 \pm 0.3 \mathrm{mM}$ ). The promoieties (phenylalanyl- and valyl-) with an unnatural amino acid (D-) exhibited slightly lower affinity to transporters than the corresponding promoieties with a natural amino acid (L-).

Table 4. $\left[{ }^{3} \mathrm{H}\right]$ Gly-Sar uptake inhibition of gemcitabine and gemcitabine prodrugs in Caco-2 cells (mean \pm S.D., $n=3$ ).

\begin{tabular}{|c|c|}
\hline Prodrug/Drug & $\mathrm{IC}_{50}$ Caco-2 (mM) \\
\hline Gemcitabine & $26.8 \pm 9.3$ \\
\hline \multicolumn{2}{|l|}{ Mono amino acid prodrugs } \\
\hline 5'-L-Phenylalanyl-gemcitabine & $0.7 \pm 0.3$ \\
\hline 5'-D-Phenylalanyl-gemcitabine & $3.4 \pm 0.7$ \\
\hline 5'-L-Valyl- gemcitabine & $1.6 \pm 0.6$ \\
\hline $5^{\prime}$-D-Valyl- gemcitabine & $2.8 \pm 1.1$ \\
\hline \multicolumn{2}{|l|}{ Dipeptide prodrugs } \\
\hline 5'-L-Phenylalanyl-L-tyrosyl-gemcitabine & $1.6 \pm 0.3$ \\
\hline
\end{tabular}

\subsection{Uptake Study of Gem and Gem Prodrugs in HFF Cells}

The uptake of mono amino acid/dipeptide monoester prodrugs of Gem and parent, Gem, was determined at $37^{\circ} \mathrm{C}$ in HFF cell. The uptake amount of all Gem prodrugs in HFF cells was 1.1- to 3.8-fold higher than their parent, Gem (Figure 2). The amounts of Gem prodrugs in HFF cells correlated with their $\log P$ values (Table 5).

Table 5. Amino acid ester prodrugs of gemcitabine.

\begin{tabular}{lc}
\hline \multicolumn{1}{c}{ Prodrug } & $\log \mathbf{P}^{\mathbf{a}}$ \\
\hline 5'-L/D-Valyl-gemcitabine & -0.37 \\
5'-L/D-Phenylalanyl-gemcitabine & 0.42 \\
5'-L-Phenylalanyl-L-tyrosyl-gemcitabine & 1.04 \\
\hline \multicolumn{2}{c}{ a Calculated using ChemDraw. }
\end{tabular}




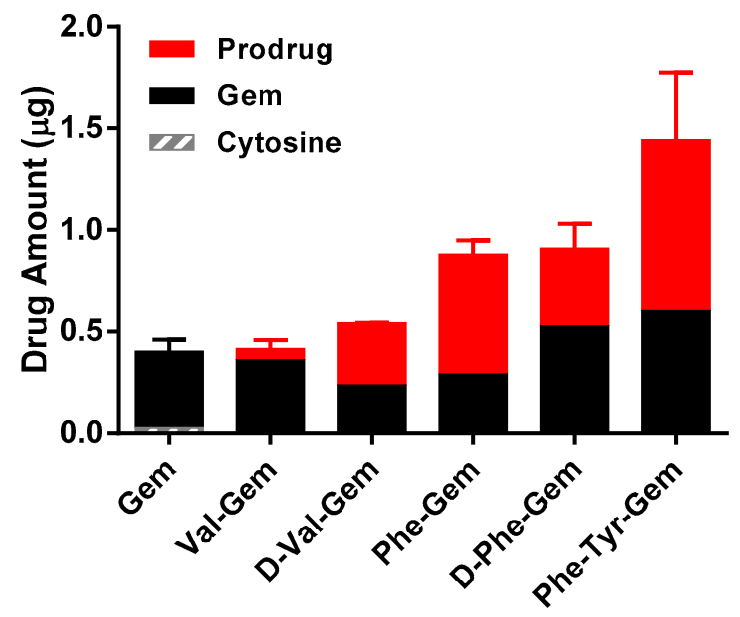

Figure 2. Uptake study of Gem and Gem prodrugs in HFF cells (Mean \pm S.D., $n=4$ ).

\subsection{HFF Cell Permeability of Gem and Gem Prodrugs}

The apical-to-basolateral permeability of mono amino acid/dipeptide monoester prodrugs of Gem and parent, Gem, was determined at $37^{\circ} \mathrm{C}$ in HFF cell monolayers. Table 6 shows the permeability values. With the exception of $5^{\prime}$-L-valyl-gemcitabine, the permeability of all Gem prodrugs across HFF monolayers was 2- to 4-fold higher than their parent, Gem. All prodrugs displayed better membrane permeability in the HFF cell monolayer.

Table 6. Apparent permeability coefficients $\left(P_{\text {app }}\right)$ of gemcitabine and monoester prodrugs of gemcitabine in the apical-to-basolateral direction across HFF monolayers (mean \pm S.D., $n=3$ ).

\begin{tabular}{|c|c|}
\hline Prodrug/Drug & $P_{a p p}, \operatorname{HFF}\left(\times 10^{-6} \mathrm{~cm} / \mathrm{s}\right)$ \\
\hline Gemcitabine & $1.6 \pm 0.1$ \\
\hline \multicolumn{2}{|l|}{ Mono amino acid prodrugs } \\
\hline 5'-L-Phenylalanyl-gemcitabine & $2.7 \pm 0.3$ \\
\hline 5'-D-Phenylalanyl-gemcitabine & $3.9 \pm 0.4$ \\
\hline $5^{\prime}$-L-Valyl-gemcitabine & $1.7 \pm 0.3$ \\
\hline 5'-D-Valyl-gemcitabine & $5.1 \pm 1.0$ \\
\hline \multicolumn{2}{|l|}{ Dipeptide prodrugs } \\
\hline $5^{\prime}$-L-Phenylalanyl-L-tyrosyl-gemcitabine & $5.1 \pm 0.3$ \\
\hline
\end{tabular}

\subsection{Cell Proliferation Assays}

$\mathrm{GI}_{50}$ values for Gem and 5'-mono amino acid/dipeptide monoester prodrugs of Gem were determined in cell proliferation studies with the pancreatic cancer cell lines, Panc- 1 and Capan-2, as shown in Table 7. All prodrugs exhibit enhanced antiproliferative activity in the three cell lines compared to parent Gem. Thus, the $\mathrm{GI}_{50}$ values of all Gem prodrugs were in the range of $2.8-7.6 \mathrm{mM}$ in Panc-1 and Capan-2 cells, as opposed to the $\mathrm{GI}_{50}$ value of $8.5 \mathrm{mM}$ for Gem in Capan-2 cells. The antiproliferative activity of Gem was not observed in Panc-1 cells. These results are consistent with trends observed in antiproliferative activity in AsPC-1 cells [38]. Interestingly, $5^{\prime}$-L-valyl-gemcitabine, 5'-D-valyl-gemcitabine, and 5'-L-phenylalanyl-L-tyrosyl-gemcitabine did not exhibit any inhibitory effect while $5^{\prime}$-L-phenylalanyl-gemcitabine, 5'-D-phenylalanyl-gemcitabine, and gemcitabine did display antiproliferative activity in MDCK cells. 
Table 7. Cell growth inhibition in Panc-1, Capan-2, and MDCK cells (mean \pm S.D., $n=3-6$ ).

\begin{tabular}{|c|c|c|c|}
\hline Prodrug/Drug & $\begin{array}{c}\mathrm{GI}_{50} \text { Panc-1 } \\
(\mathrm{mM})\end{array}$ & $\begin{array}{c}\text { GI }_{50} \text { Capan-2 } \\
(\mathrm{mM})\end{array}$ & $\begin{array}{c}\mathrm{GI}_{50} \mathrm{MDCK} \\
(\mathrm{mM})\end{array}$ \\
\hline Gemcitabine & None* & $8.5 \pm 0.2$ & $58.9 \pm 3.8$ \\
\hline \multicolumn{4}{|l|}{ Mono amino acid prodrugs } \\
\hline 5'-L-Phenylalanyl-gemcitabine & $2.8 \pm 0.1$ & $7.6 \pm 2.3$ & $7.1 \pm 2.9$ \\
\hline 5'-D-Phenylalanyl-gemcitabine & $3.0 \pm 0.1$ & $6.3 \pm 2.0$ & $79.3 \pm 3.4$ \\
\hline 5'-L-Valyl-gemcitabine & $3.0 \pm 0.3$ & $5.8 \pm 0.6$ & None \\
\hline $5^{\prime}$-D-Valyl- gemcitabine & $3.6 \pm 0.2$ & $5.5 \pm 0.8$ & None \\
\hline \multicolumn{4}{|l|}{ Dipeptide prodrugs } \\
\hline 5'-L-Phenylalanyl-L-tyrosyl-gemcitabine & $3.2 \pm 0.7$ * & $3.6 \pm 1.3$ & None \\
\hline
\end{tabular}

\section{Discussion}

Prodrug approaches, such as a parent drug coupled with an amino acid, have been widely employed to improve the intestinal absorption and oral bioavailability of poorly permeable drugs. The antivirals valacyclovir and valganciclovir $[27,49]$ are the commercially and clinically successful examples of prodrug strategies with amino acids. The improved oral bioavailability of these prodrugs [40,50] has been attributed to their enhanced transport by oligopeptide transporters in the small intestine like Pept $1[5,35,36,39,50,51]$. Following intestinal absorption, those prodrugs would then be efficiently converted to the parent drug by valacyclovirase $[52,53]$. A variety of substrates for the Pept1 transporter have been investigated to understand substrate suitability and design for further approaches [22,23,46,54-59]. We have reported the prodrug synthesis and its evaluation of mono amino acid and the dipeptide monoester prodrugs of antiviral and anticancer drugs such as floxuridine, gemcitabine, melphalan, acyclovir, oseltamivir, and 2-bromo-5,6-dichloro-1-( $\beta$-D-ribofuranosyl)benzimidazole (BDCRB) [5,6,9-11,14-20,38,39,60-62]. In this report, we describe the chemical and enzymatic stability of gemcitabine prodrugs, their affinity to transporters in Caco-2 cells, the cellular uptake and transport in HFF cells (a surrogate for stroma cell transport), and antiproliferative activity in two pancreatic duct cell lines, Panc-1 and Capan-2, along with MDCK cells. The studies demonstrated that those mono amino/dipeptide monoester prodrugs generally displayed an enhanced affinity to the PEPT1 transporter, a range of bioactivation rates, and protection of the glycosidic bond to metabolic enzymes such as thymidine phosphorylase and cytidine deaminase. Major findings of this study are: (1) enzymes had more specific stereospecificity for amino acid prodrug esters than transporters, and the promoiety with unnatural form (D-) amino acids exhibited enhanced enzymatic stability. Gemcitabine prodrugs showed resistance against the enzymes TP and CDA to maintain their prodrug structures, and the $5^{\prime}$ - position of promoieties was more effective than the $3^{\prime}$ - position; (2) amino acid/dipeptide monoester prodrugs of gemcitabine had better affinity to uptake transporters than their parent Gem and had better membrane permeability in HFF cells, indicating that gemcitabine prodrugs had the potential to reach tumor sites through stroma cells more than their parent; and (3) gemcitabine prodrugs displayed better antiproliferative activity than their parent in pancreatic cancer cells but did not exhibit cytotoxicity growth in the non-tumor cell line, MDCK cells, suggesting that the toxicity of gemcitabine prodrugs was absent or minimal, and gemcitabine prodrugs had the potential to improve the therapeutic efficacy, suggesting the necessity of prodrug activation.

The dipeptide prodrug was chemically less stable in $\mathrm{pH} 7.4$ buffer than the mono amino acid monoester prodrugs, regardless of the stereochemistry of the amino acids. Since no degradation of mono amino monoester prodrugs was observed, the dipeptide monoester prodrug likely degraded via parallel pathways similar to those suggested for Gly-Phe dipeptide alkyl ester prodrugs by Larsen and colleagues [63]. Additionally, a diketopiperazine cyclization product is also possible due to 
intramolecular condensation of the ester group with the free amino group of the dipeptide monoester prodrug. This intramolecular aminolysis has been reported, and this reaction would be negligible at pH values below 6 [63-65]. Indeed, the dipeptide monoester prodrugs were stable, and the formation of diketopiperizine was not observed at $\mathrm{pH}$ values below $6[16,18]$.

The enzymatic stability of 5'-D-phenylalanyl-gemcitabine and 5'-D-valyl-gemcitabine was significantly enhanced compared to prodrugs with the same amino acid (L-) promoiety, suggesting that the enzymes have high affinity in their substrate specificity and that unnatural form (D-) amino acids protect the enzyme-catalyzed hydrolysis of the ester linkage. Gemcitabine was quickly metabolized in the pancreatic cancer cell homogenate of Capan-2 cells, but substantial metabolism of gemcitabine was not observed in the pancreatic cancer cell homogenate of Panc-1 cells, suggesting different enzyme expression profiles. All prodrugs displayed resistance to TP and CDA but their parent, gemcitabine, was quickly metabolized. $3^{\prime}$-L-Valyl-gemcitabine also exhibited resistance to TP but the resistance was not as effective as $5^{\prime}$-L-valyl-gemcitabine, suggesting that the $5^{\prime}$-site promoiety would have structural hindrance to protect the glycosidic bond, but the $3^{\prime}$-site promoiety would not have structural hindrance as strong as the $5^{\prime}$-site (Tables 2 and 3 ).

Results of affinity studies of Gem and Gem prodrugs in Caco-2 cells were consistent with the previous report of floxuridine, which has a similar chemical structure to Gem and floxuridine prodrugs $[9,17,19]$. The transporter affinities of prodrugs with an unnatural amino acid were lower than ones with a natural amino acid (Table 4). Since, unlike Caco-2 cells, the protein expression of transporters in foreskin fibroblasts (HFF) cells is low, the prodrugs would permeate HFF cell monolayers by simple diffusion [66-68]. The results of uptake studies with gemcitabine prodrugs correlate with $\log \mathrm{P}$ values of test drugs (Table 5 and Figure 2). The uptake amounts and permeabilities of the gemcitabine prodrugs with the natural form (L-) of amino acid were consistently lower in HFF cells compared to the prodrugs with their corresponding unnatural form (D-) of amino acid (Figure 2 and Table 6). Since 5'-valyl-gemcitabine and $5^{\prime}$-phenylalanyl-gemcitabine should have the same LogP values regardless of the stereochemistry of amino acid (L-/D-), and those prodrugs exhibited different uptake amounts and different prodrug/parent drug ratios, it is suggested that the cellular accumulation of prodrugs with the natural form of amino acids are metabolized to a greater extent than prodrugs with the unnatural form of amino acids. Indeed, the prodrugs with the unnatural form of amino acids maintained more prodrug, relative to hydrolyzed drug, than ones with the natural form amino acids (Figure 2 and Table 1). Overall, these findings indicate an improvement of those prodrugs over parent drug in both stability and permeability characteristics.

Cell proliferation studies in pancreatic duct cancer cell lines confirmed the enhanced potency of the amino acid/dipeptide monoester prodrugs compared to the parent gemcitabine. The activation/metabolism of 5'-D-valyl-gemcitabine in MDCK, Panc-1, and Capan-2 cells was not observed over $2 \mathrm{~h}$ in stability studies, but the prodrug was activated and exhibited antiproliferative activity in only Panc-1 and Capan-2 cells during $24 \mathrm{~h}$. Especially in Panc-1 cells, all prodrugs exhibited tumor growth inhibition, while their parent drug, gemcitabine, did not exhibit any inhibitory activities (Table 7). Those pancreatic cancer cells that highly expressed the Pept1 transporter and amino acid/dipeptide monoester prodrugs of chemotherapeutic agents exhibited affinity for this uptake transporter [16-19,38,62]. Therefore, prodrugs are apparently delivered to a greater degree into those cancer cells, while gemcitabine is delivered to a lesser degree into the cells. Even though gemcitabine is delivered into the cancer cells, gemcitabine is quickly metabolized to non-toxic metabolites like cytosine by thymidine phosphorylase and other enzymes, which would reduce the antiproliferative activity in pancreatic cancer cells [69-71]. L-Amino acid monoester prodrugs exhibited slightly better $\mathrm{GI}_{50}$ values than D-amino acid monoester prodrugs in Panc-1 cells, while D-amino acid monoester prodrugs exhibited slightly better $\mathrm{GI}_{50}$ values than L-amino acid monoester prodrugs in Capan-2 cells, thereby suggesting that varying enzyme expression levels and species differences exist between those two pancreatic cancer cells. The $\mathrm{GI}_{50}$ values of gemcitabine prodrugs did not exhibit any discernible correlations with their permeability and/or bioactivation profiles in these cells. The different amino 
acid and stereoisomer promoieties of prodrugs would contribute to the different rates of prodrug activation inside cancer cells by particular activation enzymes. Therefore, it would be difficult to discern a meaningful correlation between $\mathrm{GI}_{50}$ values and prodrug uptake/permeabilities with limited experimental data.

The intracellular anabolism of gemcitabine prodrugs may illustrate that transported drugs and prodrugs are converted to gemcitabine and cytosine, or $\mathrm{dFdU}$ and further metabolites, via a sequential enzymatic pathway with higher concentrations of TP in tumor tissue and the ubiquitous presence of CDA (Figure 1). Taken together, our results indicate that the unnatural form amino acid monoester prodrugs of gemcitabine exhibit the potential for improved oral absorption, improved delivery into tumor sites, and enhanced antiproliferative activity. Therefore, gemcitabine prodrugs with unnatural forms of amino acid might possess advantages over ones with the natural form of amino acid for cancer target delivery, and potentially oral target delivery. Delayed enzymatic activation and enhanced metabolic resistance, along with oligopeptide transporter affinity, may facilitate the prolonged systemic circulation and enhanced therapeutic action of gemcitabine prodrugs. By demonstrating enhanced stability in biological surrogate media and cell homogenates, gemcitabine prodrugs with unnatural amino acids have potential to be developed as oral drug products with targeting to cancer cells.

\section{Materials and Methods}

\subsection{Materials}

Gemcitabine (Gem) was extracted from the lyophilized powder $\left(G^{2}\right.$ zar $\left.^{\mathrm{TM}}\right)$ supplied by Eli Lilly Pharmaceuticals (Indianapolis, IN, USA). The tert-butyloxycarbonyl (Boc) protected amino acids Boc-L-valine, Boc-L-phenylalanine, Boc-D-valine, Boc-D-phenylalanine, and Boc-L-phenylalanyl-L-tyrosine were obtained from Chem-Impex (Wood Dale, IL, USA). High-performance liquid chromatography (HPLC) grade acetonitrile was obtained from Fisher Scientific (St. Louis, MO, USA). N,N-dicyclohexylcarbodiimide (DCC), N,N-dimethylaminopyridine (DMAP), trifluoroacetic acid (TFA), and all other reagents and solvents were purchased from Aldrich Chemical Co. (Milwaukee, WI, USA). Cell culture reagents were obtained from Invitrogen (Carlsbad, CA, USA) and cell culture supplies were obtained from Corning (Corning, NY, USA) and Falcon (Lincoln Park, NJ, USA). All chemicals were either analytical or HPLC grade.

\subsection{Gemcitabine Prodrug Synthesis}

The synthesis and characterization of $5^{\prime}$-mono amino acid and dipeptide monoester prodrugs of Gem have been reported previously and synthesis was used similar to synthase Gem prodrugs [9,10,17,19,20,29]. Briefly, Boc-protected amino acid or dipeptide, (1.1 mmol), DCC $(1.1 \mathrm{mmol})$, and DMAP $(0.1 \mathrm{mmol})$ were allowed to react with Gem $(1 \mathrm{mmol})$ in $7 \mathrm{~mL}$ of dry DMF for $24 \mathrm{~h}$. The reaction progress was monitored by TLC (ethyl acetate). The reaction mixture was filtered and DMF was removed under vacuum at $40{ }^{\circ} \mathrm{C}$. The residue was extracted with ethyl acetate $(30 \mathrm{~mL})$, and washed with water $(2 \times 20 \mathrm{~mL})$ and saturated $\mathrm{NaCl}(20 \mathrm{~mL})$. The organic layer was dried over $\mathrm{MgSO}_{4}$ and concentrated under vacuum. The reaction yielded a mixture of $3^{\prime}$-monoester, $5^{\prime}$-monoester, and $3^{\prime}, 5^{\prime}$-diester Gem prodrugs. The three spots observed on TLC were separated and purified using column chromatography (dichloromethane (DCM)/methanol, 20:1). Fractions from each spot were concentrated under vacuum separately. The Boc group was cleaved by treating the residues with $5 \mathrm{~mL}$ TFA:DCM (1:1). After $4 \mathrm{~h}$, the solvent was removed and the residues were reconstituted with water and lyophilized. The TFA salts of amino acid prodrugs of Gem were obtained as white fluffy solids. The combined yield of Gem prodrugs was $\sim 60 \%$. HPLC was used to evaluate the prodrug purity. Prodrugs were between $90-99 \%$ pure. These prodrugs were easily separated from parent drug by HPLC. Electrospray ionization mass spectra (ESI-MS) were obtained on a Micromass LCT ESI-MS. The observed molecular weights of all prodrugs were found to be consistent with that required by their structure. The structural identity of the prodrugs was then confirmed using proton nuclear magnetic 
resonance spectra $\left({ }^{1} \mathrm{H}-\mathrm{NMR}\right) .{ }^{1} \mathrm{H}-\mathrm{NMR}$ spectra were obtained on a $300 \mathrm{MHz}$ Bruker DPX-300 NMR spectrometer (Billerica, MA, USA).

\subsection{Cell Culture}

Panc-1 cells (passages 22-30) and Capan-2 cells (passages 31-36) from American Type Culture Collection (Rockville, MD, USA) were routinely maintained in RPMI-1640 containing 10\% fetal bovine serum. HFF cells (passages 15-26) and MDCK cells (passages 25-32) from American Type Culture Collection (Rockville, MD, USA) were routinely maintained in DMEM containing 10\% fetal bovine serum, $1 \%$ nonessential amino acids, $1 \mathrm{mmol} / \mathrm{L}$ sodium pyruvate, and $1 \% \mathrm{~L}$-glutamine at $5 \% \mathrm{CO}_{2}$ and $90 \%$ relative humidity at $37^{\circ} \mathrm{C}$. Cells were grown in antibiotic-free media to avoid possible transport interference by antibiotics.

\subsection{Hydrolysis Studies}

Enzymatic Stability. Confluent HFF, MDCK, Panc-1, and Capan-2 cells were rinsed with saline twice. The cells were washed with $5 \mathrm{~mL}$ of $\mathrm{pH} 7.4$ phosphate buffer $(10 \mathrm{mmol} / \mathrm{L})$, lysed by ultrasonication (Micro ultrasonic cell disrupter Model KT40, Kontes, Vineland, NJ, USA), and pelleted by centrifugation for $5 \mathrm{~min}$ at $1000 \times \mathrm{g}$. The protein amount was quantified with Bio-Rad (Hercules, CA, USA) DC Protein Assay using bovine serum albumin as a standard. The protein amount was adjusted to $500 \mu \mathrm{g} / \mathrm{mL}$ and the hydrolysis reactions were carried out in 96-well plates (Corning). HFF, MDCK, Panc- 1 , and Capan- 2 cell suspensions $(250 \mu \mathrm{L})$ were placed in triplicate wells, the reactions started with the addition of substrate, and cells were incubated at $37^{\circ} \mathrm{C}$ for $120 \mathrm{~min}$. At the desired time point, sample aliquots $(35 \mu \mathrm{L})$ were removed and added to $150 \mu \mathrm{L}$ of acetonitrile (ACN) containing $0.1 \%$ TFA. The mixtures were filtered with a $0.45 \mu \mathrm{m}$ filter at $1000 \times \mathrm{g}$ for $10 \mathrm{~min}$ at $4{ }^{\circ} \mathrm{C}$. The filtrate was then analyzed via reverse-phase HPLC.

Chemical stability. The nonenzymatic hydrolysis of the prodrugs was determined as described above, except that each well contained $\mathrm{pH} 7.4$ phosphate buffer $(10 \mathrm{mmol} / \mathrm{L})$ instead of cell homogenate or human plasma.

Resistance to metabolism of gemcitabine and its prodrugs by thymidine phosphorylase. The stability of Gem and Gem prodrugs in the presence of thymidine phosphorylase (TP) was assessed by incubating the desired substrates $(200 \mu \mathrm{M})$ with TP $(2.0 \mathrm{ng} / \mu \mathrm{L})$ in phosphate buffer $(\mathrm{pH} 7.0)$ at $37^{\circ} \mathrm{C}$. Aliquots of the incubation mixture were sampled at $0,1,3,5,10,30,60$, and $120 \mathrm{~min}$, and quenched with cold acetonitrile (ACN) with $0.1 \%$ TFA, filtered through $0.45 \mu \mathrm{m}$ membrane, and analyzed for the concentrations of Gem prodrugs and Gem by HPLC.

Resistance to metabolism of gemcitabine and its prodrugs by cytidine deaminase. The stability of Gem and Gem prodrugs in the presence of cytidine deaminase (CDA) was assessed by incubating the desired substrates $(200 \mu \mathrm{M})$ with CDA $(5.0 \mathrm{ng} / \mu \mathrm{L})$ in phosphate buffer $(\mathrm{pH} 6.5)$ at $37^{\circ} \mathrm{C}$. Aliquots of the incubation mixture were sampled at $0,3,5,10,30,60$, and $120 \mathrm{~min}$, and quenched with cold acetonitrile (ACN) with $0.1 \%$ TFA, filtered through $0.45 \mu \mathrm{m}$ membrane, and analyzed for the concentrations of Gem prodrugs and Gem by HPLC.

\section{5. $\left[{ }^{3} H\right]$ Gly-Sar Uptake Inhibition}

Caco-2 cells at 10 days postseeding were incubated with $10 \mu \mathrm{mol} / \mathrm{L}$ Gly-Sar $(9.98 \mu \mathrm{mol} / \mathrm{L}$ Gly-Sar and $0.02 \mu \mathrm{mol} / \mathrm{L}\left[{ }^{3} \mathrm{H}\right]$ Gly-Sar (Moravek Biochemicals, Brea, CA, USA)), along with various concentrations $(5-0.05 \mathrm{mmol} / \mathrm{L})$ of Gem and Gem prodrugs for $30 \mathrm{~min}$. After the incubation, the drug solution was removed. The cells were gently washed three times with ice-cold PBS and solubilized with $2 \mathrm{~mL}$ of scintillation cocktail (ScintiVerse, Fisher Scientific, St. Louis, MO, USA), and the radioactivity was determined by scintillation counting (Beckman LS-9000, Beckman Instruments, Fullerton, CA, USA). Inhibitory concentration $50\left(\mathrm{IC}_{50}\right)$ values were determined using nonlinear data fitting (GraphPad Prism version 6, GraphPad Software, Inc., La Jolla, CA, USA). 


\subsection{Uptake Study of Gemcitabine Prodrugs and Gemcitabine in HFF Cells}

HFF cells were grown on a 12-well plate for 24 days. Wells were rinsed with MES ( $\mathrm{pH}$ 6.0) buffer twice. Fresh MES buffer was reapplied to each well and incubated at $37^{\circ} \mathrm{C}$ for $15 \mathrm{~min}$. Each drug was individually tested from freshly prepared solutions in MES buffer $(0.1 \mathrm{mM}$, total $0.3 \mathrm{~mL})$. The solution was placed in each well and incubated at $37^{\circ} \mathrm{C}$ for $30 \mathrm{~min}$. Drug solution was removed and $3 \mathrm{~mL}$ of ice-cold PBS was immediately placed in each well. Each well was rinsed with $3 \mathrm{~mL}$ of cold-PBS twice and $0.5 \mathrm{~mL}$ of methanol: $\mathrm{H}_{2} \mathrm{O}(1: 1)$ containing $0.1 \%$ TFA was placed in each well. The cell suspension was collected and transferred to a new tube. Those tubes were spun at $1000 \times g$ at $4{ }^{\circ} \mathrm{C}$ for $5 \mathrm{~min}$. The supernatant was mixed with an equal amount of water with either $0.1 \%$ formic acid or $0.1 \%$ ammonium hydroxide for HPLC analysis. The cell pellets were used to determine the protein amount with the Bio-Rad (Hercules, CA, USA) DC Protein Assay using bovine serum albumin as a standard.

\subsection{Transepithelial Transport Studies in HFF Cells}

HFF cell monolayers were grown on collagen-coated polytetrafluoroethylene membranes for 28 days. Transepithelial electrical resistance (TEER) was monitored and values above $180 \Omega / \mathrm{cm}^{2}$ in HFF cells were used in the study. Apical and basolateral sides of the transwell inserts were washed with MES ( $\mathrm{pH}$ 6.0) and HEPES (pH 7.4), respectively. Fresh MES and HEPES buffers were reapplied to transwell inserts and incubated at $37^{\circ} \mathrm{C}$ for $15 \mathrm{~min}$. A freshly prepared $0.1 \mathrm{mM}$ drug solution in MES buffer was placed in the donor chamber and the receiver chamber was filled with HEPES buffer. The volumes of donor and receiver chambers were $0.5 \mathrm{~mL}$ and $1.5 \mathrm{~mL}$, respectively. The area of the exposed monolayer was $1.12 \mathrm{~cm}^{2}$. Sampling from the receiver chamber $(100 \mu \mathrm{L})$ was conducted up to a period of $2 \mathrm{~h}$ at $15,30,45,60,75,90,105$, and $120 \mathrm{~min}$, at $37^{\circ} \mathrm{C}$, and replaced with an equal volume of fresh HEPES buffer to maintain sink conditions in the receiver chamber. All samples were immediately acidified with $0.1 \%$ TFA and analyzed by HPLC.

\subsection{Data Analysis}

The initial rates of hydrolysis were used to obtain the apparent first-order rate constants and subsequent half-lives. The apparent first-order degradation rate constants of various Gem prodrugs at $37^{\circ} \mathrm{C}$ were determined by plotting the logarithm of the prodrug remaining as a function of time. The slopes of these plots are related to the rate constant, $\mathrm{k}$, and given by

$$
\mathrm{k}=2.303 \times \text { slope }(\log \mathrm{C} \text { vs. time })
$$

The degradation half-lives were then calculated by the equation,

$$
\mathrm{t}_{1 / 2}=0.693 / \mathrm{k}
$$

Statistical significance was evaluated with GraphPad Prism version 6.0 (La Jolla, CA, USA) by performing a one-way analysis of variance with post-hoc Tukey's test to compare means.

The apparent permeability $\left(P_{a p p}\right)$ for the prodrugs was calculated using the following equations:

$$
\text { Flux }=J_{s s}=d M / d t
$$

where $J_{s s}$ is the steady state flux, $M$ is the cumulative amount of prodrug, and regenerated mono amino acid prodrug, drug, and cytosine is in the receiver compartment. The concentrations of Gem and Gem prodrugs in the receiver and donor compartments were analyzed using HPLC.

\subsection{HPLC Analysis}

The concentrations of prodrugs and their metabolites were determined with an Agilent HPLC system (Agilent Technologies, Santa Clara, CA, USA). The HPLC system consisted of Agilent pumps 
(1100 series), an Agilent autosampler (1200 series), and an Agilent UV-Vis detector (1100 series) controlled by Chemstation ${ }^{\circledR} 32$ software. Samples were resolved in the Agilent Eclipse XDB-C 18 reverse-phase column $(3.5 \mu \mathrm{m}, 4.6 \times 150 \mathrm{~mm})$, equipped with a guard column for gemcitabine and gemcitabine prodrugs. The mobile phase consisted of $0.1 \%$ TFA/water (Solvent A) and $0.1 \%$ TFA/acetonitrile (Solvent B) with the solvent B gradient changing from $0-56 \%$ at a rate of $2 \% / \mathrm{min}$ during a $14 \mathrm{~min}$ run. Standard curves generated for cytosine, Gem, and Gem prodrugs were utilized for the quantitation of the integrated area under peaks. The detection wavelength was $254 \mathrm{~nm}$ and 280 nm for drug compounds.

\subsection{Cell Proliferation Assays}

Cell proliferation studies were conducted with MDCK, Panc-1, and Capan-2 cell lines. The cells were seeded onto 96-well plates at 125,000 cells per well and allowed to attach/grow for $24 \mathrm{~h}$ before drug solutions were added. The culture medium (RPMI-1640 $+10 \%$ fetal bovine serum) was removed and the cells were gently washed once with sterile $\mathrm{pH} 6.0$ uptake buffer. Gem and Gem prodrugs were serially diluted in $\mathrm{pH} 6.0$ uptake buffer from 5 to $0.25 \mathrm{mmol} / \mathrm{L}$. Buffer alone was used as $100 \%$ viability control. The wash buffer was removed and $25 \mu \mathrm{L}$ drug solution per well was added and incubated at $37{ }^{\circ} \mathrm{C}$ for $4 \mathrm{~h}$ with MDCK, Panc-1, and Capan-2 cells in the cell incubator. After this time period, the drug solutions were removed and the cells were gently washed twice with sterile uptake buffer. The culture medium was then added to each well after washing. The cells were allowed to recover for $24 \mathrm{~h}$ before evaluating cell viability via 2,3-bis[2-methoxy-4-nitro-5-sulfophenyl]-2H-tetrazolium-5-carboxanilide inner salt (XTT) assays. A mixture $(30 \mu \mathrm{L})$ containing XTT in sterile RPMI-1640 without phenol red $(1 \mathrm{mg} / \mathrm{mL})$ and phenazine methosulfate ( $N$-methyl dibenzopyrazine methyl sulfate in sterile PBS, $0.383 \mathrm{mg} / \mathrm{mL}$ ) reagents were added to the cells and incubated at $37^{\circ} \mathrm{C}$ for $1 \mathrm{~h}$ for the color to develop. Absorbance readings at $450 \mathrm{~nm}$ were recorded. The data were plotted and the $\mathrm{GI}_{50}$ values, with a concentration showing $50 \%$ of the cell growth inhibitory effect, were calculated using GraphPad Prism version 6.0 (La Jolla, CA, USA) by nonlinear data fitting.

Acknowledgments: This work was supported by grant R01GM115481.

Author Contributions: Yasuhiro Tsume and Adam J. Drelich performed the experiments; Yasuhiro Tsume analyzed the data; Yasuhiro Tsume wrote the paper and David E. Smith and Gordon L. Amidon supervised the paper.

Conflicts of Interest: The authors declare no conflict of interest.

\section{References}

1. Alvarellos, M.L.; Lamba, J.; Sangkuhl, K.; Thorn, C.F.; Wang, L.; Klein, D.J.; Altman, R.B.; Klein, T.E. Pharmgkb summary: Gemcitabine pathway. Pharm. Genom. 2014, 24, 564-574. [CrossRef] [PubMed]

2. Wong, A.; Soo, R.A.; Yong, W.P.; Innocenti, F. Clinical pharmacology and pharmacogenetics of gemcitabine. Drug Metab. Rev. 2009, 41,77-88. [CrossRef] [PubMed]

3. Mini, E.; Nobili, S.; Caciagli, B.; Landini, I.; Mazzei, T. Cellular pharmacology of gemcitabine. Ann. Oncol. 2006, 17 (Suppl. 5), v7-v12. [CrossRef] [PubMed]

4. Gupta, S.V.; Gupta, D.; Sun, J.; Dahan, A.; Tsume, Y.; Hilfinger, J.; Lee, K.D.; Amidon, G.L. Enhancing the intestinal membrane permeability of zanamivir: A carrier mediated prodrug approach. Mol. Pharm. 2011, 8 , 2358-2367. [CrossRef] [PubMed]

5. Han, H.; de Vrueh, R.L.; Rhie, J.K.; Covitz, K.M.; Smith, P.L.; Lee, C.P.; Oh, D.M.; Sadee, W.; Amidon, G.L. $5^{\prime}$-amino acid esters of antiviral nucleosides, acyclovir, and azt are absorbed by the intestinal pept1 peptide transporter. Pharm. Res. 1998, 15, 1154-1159. [CrossRef] [PubMed]

6. Incecayir, T.; Sun, J.; Tsume, Y.; Xu, H.; Gose, T.; Nakanishi, T.; Tamai, I.; Hilfinger, J.; Lipka, E.; Amidon, G.L. Carrier-mediated prodrug uptake to improve the oral bioavailability of polar drugs: An application to an oseltamivir analogue. J. Pharm. Sci. 2016, 105, 925-934. [CrossRef] [PubMed] 
7. Kim, D.K.; Lee, N.; Kim, Y.W.; Chang, K.; Im, G.J.; Choi, W.S.; Kim, K.H. Synthesis and evaluation of amino acid esters of 6-deoxypenciclovir as potential prodrugs of penciclovir. Bioorg. Med. Chem. 1999, 7, 419-424. [CrossRef]

8. Krecmerova, M. Amino acid ester prodrugs of nucleoside and nucleotide antivirals. Mini Rev. Med. Chem. 2017, 17, 818-833. [CrossRef] [PubMed]

9. Landowski, C.P.; Song, X.; Lorenzi, P.L.; Hilfinger, J.M.; Amidon, G.L. Floxuridine amino acid ester prodrugs: Enhancing caco-2 permeability and resistance to glycosidic bond metabolism. Pharm. Res. 2005, 22, 1510-1518. [CrossRef] [PubMed]

10. Landowski, C.P.; Vig, B.S.; Song, X.; Amidon, G.L. Targeted delivery to pept1-overexpressing cells: Acidic, basic, and secondary floxuridine amino acid ester prodrugs. Mol. Cancer Ther. 2005, 4, 659-667. [CrossRef] [PubMed]

11. Mittal, S.; Tsume, Y.; Landowski, C.P.; Lee, K.D.; Hilfinger, J.M.; Amidon, G.L. Proline prodrug of melphalan, prophalan-1, demonstrates high therapeutic index in a murine melanoma model. Eur. J. Pharm. BioPharm. 2007, 67, 752-758. [CrossRef] [PubMed]

12. Ninomiya, M.; Tanaka, K.; Tsuchida, Y.; Muto, Y.; Koketsu, M.; Watanabe, K. Increased bioavailability of tricin-amino acid derivatives via a prodrug approach. J. Med. Chem. 2011, 54, 1529-1536. [CrossRef] [PubMed]

13. Shin, H.C.; Kim, J.S.; Vig, B.S.; Song, X.; Drach, J.C.; Amidon, G.L. Interaction of intestinal nucleoside transporter hent2 with amino acid ester prodrugs of floxuridine and 2-bromo-5,6-dichloro-1-beta-D-ribofuranosylbenzimidazole. Biol. Pharm. Bull. 2006, 29, 247-252. [CrossRef] [PubMed]

14. Song, X.; Lorenzi, P.L.; Landowski, C.P.; Vig, B.S.; Hilfinger, J.M.; Amidon, G.L. Amino acid ester prodrugs of the anticancer agent gemcitabine: Synthesis, bioconversion, metabolic bioevasion, and hpept1-mediated transport. Mol. Pharm. 2005, 2, 157-167. [CrossRef] [PubMed]

15. Song, X.; Vig, B.S.; Lorenzi, P.L.; Drach, J.C.; Townsend, L.B.; Amidon, G.L. Amino acid ester prodrugs of the antiviral agent 2-bromo-5,6-dichloro-1-(beta-D-ribofuranosyl)benzimidazole as potential substrates of hpept1 transporter. J. Med. Chem. 2005, 48, 1274-1277. [CrossRef] [PubMed]

16. Tsume, Y.; Borras Bermejo, B.; Amidon, G.L. The dipeptide monoester prodrugs of floxuridine and gemcitabine-feasibility of orally administrable nucleoside analogs. Pharmaceuticals 2014, 7, 169-191. [CrossRef] [PubMed]

17. Tsume, Y.; Hilfinger, J.M.; Amidon, G.L. Enhanced cancer cell growth inhibition by dipeptide prodrugs of floxuridine: Increased transporter affinity and metabolic stability. Mol. Pharm. 2008, 5, 717-727. [CrossRef] [PubMed]

18. Tsume, Y.; Hilfinger, J.M.; Amidon, G.L. Potential of amino acid/dipeptide monoester prodrugs of floxuridine in facilitating enhanced delivery of active drug to interior sites of tumors: A two-tier monolayer in vitro study. Pharm. Res. 2011, 28, 2575-2588. [CrossRef] [PubMed]

19. Tsume, Y.; Vig, B.S.; Sun, J.; Landowski, C.P.; Hilfinger, J.M.; Ramachandran, C.; Amidon, G.L. Enhanced absorption and growth inhibition with amino acid monoester prodrugs of floxuridine by targeting hpept1 transporters. Molecules 2008, 13, 1441-1454. [CrossRef] [PubMed]

20. Vig, B.S.; Lorenzi, P.J.; Mittal, S.; Landowski, C.P.; Shin, H.C.; Mosberg, H.I.; Hilfinger, J.M.; Amidon, G.L. Amino acid ester prodrugs of floxuridine: Synthesis and effects of structure, stereochemistry, and site of esterification on the rate of hydrolysis. Pharm. Res. 2003, 20, 1381-1388. [CrossRef] [PubMed]

21. Wu, Z.; Drach, J.C.; Prichard, M.N.; Yanachkova, M.; Yanachkov, I.; Bowlin, T.L.; Zemlicka, J. L-valine ester of cyclopropavir: A new antiviral prodrug. Antivir. Chem. Chemother. 2009, 20, 37-46. [CrossRef] [PubMed]

22. Anand, B.S.; Patel, J.; Mitra, A.K. Interactions of the dipeptide ester prodrugs of acyclovir with the intestinal oligopeptide transporter: Competitive inhibition of glycylsarcosine transport in human intestinal cell line-caco-2. J. Pharmacol. Exp. Ther. 2003, 304, 781-791. [CrossRef] [PubMed]

23. Friedrichsen, G.M.; Chen, W.; Begtrup, M.; Lee, C.P.; Smith, P.L.; Borchardt, R.T. Synthesis of analogs of L-valacyclovir and determination of their substrate activity for the oligopeptide transporter in caco-2 cells. Eur. J. Pharm. Sci. 2002, 16, 1-13. [CrossRef]

24. Guo, A.; Hu, P.; Balimane, P.V.; Leibach, F.H.; Sinko, P.J. Interactions of a nonpeptidic drug, valacyclovir, with the human intestinal peptide transporter (hpept1) expressed in a mammalian cell line. J. Pharmacol. Exp. Ther. 1999, 289, 448-454. [PubMed] 
25. Landowski, C.P.; Sun, D.; Foster, D.R.; Menon, S.S.; Barnett, J.L.; Welage, L.S.; Ramachandran, C.; Amidon, G.L. Gene expression in the human intestine and correlation with oral valacyclovir pharmacokinetic parameters. J. Pharmacol. Exp. Ther. 2003, 306, 778-786. [CrossRef] [PubMed]

26. Phan, D.D.; Chin-Hong, P.; Lin, E.T.; Anderle, P.; Sadee, W.; Guglielmo, B.J. Intra- and interindividual variabilities of valacyclovir oral bioavailability and effect of coadministration of an hpept1 inhibitor. Antimicrob. Agents Chemother. 2003, 47, 2351-2353. [CrossRef] [PubMed]

27. Umapathy, N.S.; Ganapathy, V.; Ganapathy, M.E. Transport of amino acid esters and the amino-acid-based prodrug valganciclovir by the amino acid transporter atb(0,+). Pharm. Res. 2004, 21, 1303-1310. [CrossRef] [PubMed]

28. Pennycooke, M.; Chaudary, N.; Shuralyova, I.; Zhang, Y.; Coe, I.R. Differential expression of human nucleoside transporters in normal and tumor tissue. BioChem. Biophys. Res. Commun. 2001, 280, 951-959. [CrossRef] [PubMed]

29. Advani, A.S.; Shadman, M.; Ali-Osman, F.; Barker, A.; Rybicki, L.; Kalaycio, M.; Sekeres, M.A.; de Castro, C.M.; Diehl, L.F.; Moore, J.O.; et al. A phase ii trial of gemcitabine and mitoxantrone for patients with acute myeloid leukemia in first relapse. Clin. Lymphoma Myeloma Leuk. 2010, 10, 473-476. [CrossRef] [PubMed]

30. Spratlin, J.; Sangha, R.; Glubrecht, D.; Dabbagh, L.; Young, J.D.; Dumontet, C.; Cass, C.; Lai, R.; Mackey, J.R. The absence of human equilibrative nucleoside transporter 1 is associated with reduced survival in patients with gemcitabine-treated pancreas adenocarcinoma. Clin. Cancer Res. 2004, 10, 6956-6961. [CrossRef] [PubMed]

31. Marechal, R.; Bachet, J.B.; Mackey, J.R.; Dalban, C.; Demetter, P.; Graham, K.; Couvelard, A.; Svrcek, M.; Bardier-Dupas, A.; Hammel, P.; et al. Levels of gemcitabine transport and metabolism proteins predict survival times of patients treated with gemcitabine for pancreatic adenocarcinoma. Gastroenterology 2012, 143, 664-674. [CrossRef] [PubMed]

32. Greenhalf, W.; Ghaneh, P.; Neoptolemos, J.P.; Palmer, D.H.; Cox, T.F.; Lamb, R.F.; Garner, E.; Campbell, F.; Mackey, J.R.; Costello, E.; et al. Pancreatic cancer hent1 expression and survival from gemcitabine in patients from the espac-3 trial. J. Natl. Cancer Inst. 2014, 106, djt347. [CrossRef] [PubMed]

33. Liu, Z.Q.; Han, Y.C.; Zhang, X.; Chu, L.; Fang, J.M.; Zhao, H.X.; Chen, Y.J.; Xu, Q. Prognostic value of human equilibrative nucleoside transporter1 in pancreatic cancer receiving gemcitabin-based chemotherapy: A meta-analysis. PLoS ONE 2014, 9, e87103.

34. Zhang, J.; Visser, F.; King, K.M.; Baldwin, S.A.; Young, J.D.; Cass, C.E. The role of nucleoside transporters in cancer chemotherapy with nucleoside drugs. Cancer Metastasis Rev. 2007, 26, 85-110. [CrossRef] [PubMed]

35. Yang, B.; Hu, Y.; Smith, D.E. Impact of peptide transporter 1 on the intestinal absorption and pharmacokinetics of valacyclovir after oral dose escalation in wild-type and pept1 knockout mice. Drug Metab. Dispos. 2013, 41, 1867-1874. [CrossRef] [PubMed]

36. Yang, B.; Smith, D.E. Significance of peptide transporter 1 in the intestinal permeability of valacyclovir in wild-type and pept1 knockout mice. Drug Metab. Dispos. 2013, 41, 608-614. [CrossRef] [PubMed]

37. Rubio-Aliaga, I.; Daniel, H. Mammalian peptide transporters as targets for drug delivery. Trends Pharmacol. Sci. 2002, 23, 434-440. [CrossRef]

38. Tsume, Y.; Incecayir, T.; Song, X.; Hilfinger, J.M.; Amidon, G.L. The development of orally administrable gemcitabine prodrugs with D-enantiomer amino acids: Enhanced membrane permeability and enzymatic stability. Eur. J. Pharm. BioPharm. 2014, 86, 514-523. [CrossRef] [PubMed]

39. Han, H.K.; Oh, D.M.; Amidon, G.L. Cellular uptake mechanism of amino acid ester prodrugs in caco-2/hpept1 cells overexpressing a human peptide transporter. Pharm. Res. 1998, 15, 1382-1386. [CrossRef] [PubMed]

40. Weller, S.; Blum, M.R.; Doucette, M.; Burnette, T.; Cederberg, D.M.; de Miranda, P.; Smiley, M.L. Pharmacokinetics of the acyclovir pro-drug valaciclovir after escalating single- and multiple-dose administration to normal volunteers. Clin. Pharmacol. Ther. 1993, 54, 595-605. [CrossRef] [PubMed]

41. Gonzalez, D.E.; Covitz, K.M.; Sadee, W.; Mrsny, R.J. An oligopeptide transporter is expressed at high levels in the pancreatic carcinoma cell lines aspc-1 and capan-2. Cancer Res. 1998, 58, 519-525. [PubMed]

42. Birnie, G.D.; Kroeger, H.; Heidelberger, C. Studies of fluorinated pyrimidines. Xviii. The degradation of 5-fluoro-2'-deoxyuridine and related compounds by nucleoside phosphorylase. Biochemistry 1963, 2, 566-572. [CrossRef] [PubMed] 
43. Serdjebi, C.; Seitz, J.F.; Ciccolini, J.; Duluc, M.; Norguet, E.; Fina, F.; Lacarelle, B.; Ouafik, L.; Dahan, L. Rapid deaminator status is associated with poor clinical outcome in pancreatic cancer patients treated with a gemcitabine-based regimen. Pharmacogenomics 2013, 14, 1047-1051. [CrossRef] [PubMed]

44. Baker, J.A.; Wickremsinhe, E.R.; Li, C.H.; Oluyedun, O.A.; Dantzig, A.H.; Hall, S.D.; Qian, Y.W.; Ring, B.J.; Wrighton, S.A.; Guo, Y. Pharmacogenomics of gemcitabine metabolism: Functional analysis of genetic variants in cytidine deaminase and deoxycytidine kinase. Drug Metab. Dispos. 2013, 41, 541-545. [CrossRef] [PubMed]

45. Carlier, C.; Mathys, A.; De Jaeghere, E.; Steuperaert, M.; De Wever, O.; Ceelen, W. Tumour tissue transport after intraperitoneal anticancer drug delivery. Int. J. Hyperthermia 2017, 33, 534-542. [CrossRef] [PubMed]

46. Meredith, D.; Temple, C.S.; Guha, N.; Sword, C.J.; Boyd, C.A.; Collier, I.D.; Morgan, K.M.; Bailey, P.D. Modified amino acids and peptides as substrates for the intestinal peptide transporter pept1. Eur. J. BioChem. 2000, 267, 3723-3728. [CrossRef] [PubMed]

47. Bouzin, C.; Feron, O. Targeting tumor stroma and exploiting mature tumor vasculature to improve anti-cancer drug delivery. Drug Resist. Update 2007, 10, 109-120. [CrossRef] [PubMed]

48. Desmouliere, A.; Guyot, C.; Gabbiani, G. The stroma reaction myofibroblast: A key player in the control of tumor cell behavior. Int. J. Dev. Biol. 2004, 48, 509-517. [CrossRef] [PubMed]

49. Anand, B.S.; Dey, S.; Mitra, A.K. Current prodrug strategies via membrane transporters/receptors. Expert Opin. Biol. Ther. 2002, 2, 607-620. [CrossRef] [PubMed]

50. Steingrimsdottir, H.; Gruber, A.; Palm, C.; Grimfors, G.; Kalin, M.; Eksborg, S. Bioavailability of aciclovir after oral administration of aciclovir and its prodrug valaciclovir to patients with leukopenia after chemotherapy. Antimicrob. Agents Chemother. 2000, 44, 207-209. [CrossRef] [PubMed]

51. Ganapathy, M.E.; Huang, W.; Wang, H.; Ganapathy, V.; Leibach, F.H. Valacyclovir: A substrate for the intestinal and renal peptide transporters pept1 and pept2. BioChem. Biophys. Res. Commun. 1998, 246, 470-475. [CrossRef] [PubMed]

52. Kim, I.; Chu, X.Y.; Kim, S.; Provoda, C.J.; Lee, K.D.; Amidon, G.L. Identification of a human valacyclovirase: Biphenyl hydrolase-like protein as valacyclovir hydrolase. J. Biol. Chem. 2003, 278, 25348-25356. [CrossRef] [PubMed]

53. Kim, I.; Song, X.; Vig, B.S.; Mittal, S.; Shin, H.C.; Lorenzi, P.J.; Amidon, G.L. A novel nucleoside prodrug-activating enzyme: Substrate specificity of biphenyl hydrolase-like protein. Mol. Pharm. 2004, 1, 117-127. [CrossRef] [PubMed]

54. Eriksson, A.H.; Elm, P.L.; Begtrup, M.; Nielsen, R.; Steffansen, B.; Brodin, B. Hpept1 affinity and translocation of selected gln-sar and glu-sar dipeptide derivatives. Mol. Pharm. 2005, 2, 242-249. [CrossRef] [PubMed]

55. Li, J.; Tamura, K.; Lee, C.P.; Smith, P.L.; Borchardt, R.T.; Hidalgo, I.J. Structure-affinity relationships of val-val and val-val-val stereoisomers with the apical oligopeptide transporter in human intestinal caco-2 cells. J. Drug Target. 1998, 5, 317-327. [CrossRef] [PubMed]

56. Nielsen, C.U.; Andersen, R.; Brodin, B.; Frokjaer, S.; Taub, M.E.; Steffansen, B. Dipeptide model prodrugs for the intestinal oligopeptide transporter. Affinity for and transport via hpept1 in the human intestinal caco-2 cell line. J. Control. Release 2001, 76, 129-138. [CrossRef]

57. Tamura, K.; Bhatnagar, P.K.; Takata, J.S.; Lee, C.P.; Smith, P.L.; Borchardt, R.T. Metabolism, uptake, and transepithelial transport of the diastereomers of val-val in the human intestinal cell line, caco-2. Pharm. Res. 1996, 13, 1213-1218. [CrossRef] [PubMed]

58. Vabeno, J.; Lejon, T.; Nielsen, C.U.; Steffansen, B.; Chen, W.; Ouyang, H.; Borchardt, R.T.; Luthman, K. Phe-gly dipeptidomimetics designed for the di-/tripeptide transporters pept1 and pept2: Synthesis and biological investigations. J. Med. Chem. 2004, 47, 1060-1069. [CrossRef] [PubMed]

59. Anand, B.S.; Katragadda, S.; Mitra, A.K. Pharmacokinetics of novel dipeptide ester prodrugs of acyclovir after oral administration: Intestinal absorption and liver metabolism. J. Pharmacol. Exp. Ther. 2004, 311, 659-667. [CrossRef] [PubMed]

60. Lorenzi, P.L.; Landowski, C.P.; Song, X.; Borysko, K.Z.; Breitenbach, J.M.; Kim, J.S.; Hilfinger, J.M.; Townsend, L.B.; Drach, J.C.; Amidon, G.L. Amino acid ester prodrugs of 2-bromo-5,6-dichloro-1-(beta-D-ribofuranosyl)benzimidazole enhance metabolic stability in vitro and in vivo. J. Pharmacol. Exp. Ther. 2005, 314, 883-890. [CrossRef] [PubMed] 
61. Tsume, Y.; Amidon, G.L. Selection of suitable prodrug candidates for in vivo studies via in vitro studies; the correlation of prodrug stability in between cell culture homogenates and human tissue homogenates. J. Pharm. Pharm. Sci. 2012, 15, 433-446. [CrossRef] [PubMed]

62. Tsume, Y.; Amidon, G.L. The feasibility of enzyme targeted activation for amino acid/dipeptide monoester prodrugs of floxuridine; cathepsin d as a potential targeted enzyme. Molecules 2012, 17, 3672-3689. [CrossRef] [PubMed]

63. Larsen, S.W.; Ankersen, M.; Larsen, C. Kinetics of degradation and oil solubility of ester prodrugs of a model dipeptide (gly-phe). Eur. J. Pharm. Sci. 2004, 22, 399-408. [CrossRef] [PubMed]

64. Goolcharran, C.; Borchardt, R.T. Kinetics of diketopiperazine formation using model peptides. J. Pharm. Sci. 1998, 87, 283-288. [CrossRef] [PubMed]

65. Jensen, E.; Bundgaard, H. Peptide esters as water-soluble prodrugs for hydroxyl containing agents: Chemical stability and enzymatic hydrolysis of benzyl esters of glycine, diglycine and triglycine. Int. J. Pharm. 1991, 71, 117-125. [CrossRef]

66. Juuti-Uusitalo, K.; Vaajasaari, H.; Ryhanen, T.; Narkilahti, S.; Suuronen, R.; Mannermaa, E.; Kaarniranta, K.; Skottman, H. Efflux protein expression in human stem cell-derived retinal pigment epithelial cells. PLoS ONE 2012, 7, e30089. [CrossRef] [PubMed]

67. Marthandan, S.; Priebe, S.; Baumgart, M.; Groth, M.; Cellerino, A.; Guthke, R.; Hemmerich, P.; Diekmann, S. Similarities in gene expression profiles during in vitro aging of primary human embryonic lung and foreskin fibroblasts. Biomed. Res. Int. 2015, 2015, 731938. [CrossRef] [PubMed]

68. Germanguz, I.; Sedan, O.; Zeevi-Levin, N.; Shtrichman, R.; Barak, E.; Ziskind, A.; Eliyahu, S.; Meiry, G.; Amit, M.; Itskovitz-Eldor, J.; et al. Molecular characterization and functional properties of cardiomyocytes derived from human inducible pluripotent stem cells. J. Cell. Mol. Med. 2011, 15, 38-51. [CrossRef] [PubMed]

69. Plunkett, W.; Huang, P.; Searcy, C.E.; Gandhi, V. Gemcitabine: Preclinical pharmacology and mechanisms of action. Semin. Oncol. 1996, 23, 3-15. [PubMed]

70. Shipley, L.A.; Brown, T.J.; Cornpropst, J.D.; Hamilton, M.; Daniels, W.D.; Culp, H.W. Metabolism and disposition of gemcitabine, and oncolytic deoxycytidine analog, in mice, rats, and dogs. Drug Metab. Dispos. 1992, 20, 849-855. [PubMed]

71. Stuurman, F.E.; Nuijen, B.; Beijnen, J.H.; Schellens, J.H. Oral anticancer drugs: Mechanisms of low bioavailability and strategies for improvement. Clin. Pharmacokinet. 2013, 52, 399-414. [CrossRef] [PubMed]

Sample Availability: Not available.

(C) 2017 by the authors. Licensee MDPI, Basel, Switzerland. This article is an open access article distributed under the terms and conditions of the Creative Commons Attribution (CC BY) license (http:/ / creativecommons.org/licenses/by/4.0/). 